\title{
Problems Of Base Erosion And Anti-Abuse Tax
}

\author{
J. G. S. Yang, and L. J. Lauricella
}

\begin{abstract}
The United States (U.S.) has a new tax law known as The Tax Cuts and Jobs Act of 2017 (TCJA) [1]. It imposes many new provisions dealing with international tax from a U.S. perspective, including several that were designed to prevent the erosion of the U.S. tax base. This article discusses the reasons for these new anti-base erosion provisions and explains how they work. It points out some of the international tax planning techniques used by U.S. and other multinational corporations to shelter income from high taxes. It discusses the temporary and in some cases permanent disallowance of deductions for interest expense, the disallowance of royalty expenses, and the new base erosion and anti-abuse tax (BEAT). This paper also presents examples and offer tax planning strategies.
\end{abstract}

Index Terms - Tax Cuts and Jobs Act of 2017, Worldwide Tax System, Territorial Tax System, Controlled Foreign Corporation, Base Erosion Payment, Base Erosion and Antiabuse Tax.

\section{INTRODUCTION}

\section{A. U.S. Taxation}

Prior to 2018 (and continuing today) the U.S. taxed all income earned by U.S. corporations, regardless of where the income was earned. Foreign corporations, including subsidiaries of U.S. corporations generally were subject to U.S. tax on income earned in the U.S. that was considered effectively connected with a U.S. trade or business. Most other U.S. sourced income of a foreign corporation was taxed by withholding as fixed or determinable annual or periodical income. Extensive U.S. rules determined where the source of income derived from which then was used to determine whether such income was subject to U.S. tax.

Since the pre-2018 U.S. statutory corporate tax rate of $35 \%$ was higher than that in many foreign countries, U.S. corporations were incentivized to conduct foreign source activities in non-U.S. corporations. Anti-abuse rules such as subpart-F income and intercompany pricing rules under section 482 were available to prevent artificially transferring U.S. income to a foreign corporation.

In general, the foreign source income of a foreign corporation was not subject to U.S. tax until such time as the foreign corporation paid a dividend to its U.S. parent. It is estimated that more than $\$ 2$ trillion in not yet taxed profits are in foreign subsidiaries [2]. Foreign based companies were subject to similar rules for their U.S. activities. If they operated through a U.S. subsidiary, the world-wide income of that subsidiary was subject to U.S. tax. If they operated

Published on July 13, 2020.

J. G. S. Yang, Montclair State University, USA.

(corresponding e-mail: yangg ${ }^{\circledR}$ montclair.edu)

L. J. Lauricella, Montclair State University, USA.

(e-mail: lauricellal@montclair.edu). through a U.S. branch of a foreign corporation, only the income effectively connected with a U.S. trade or business would be taxed in the U.S.

The income taxed by the U.S. could be reduced by having the branch or U.S. subsidiary make tax deductible payments to related non-U.S. entities. Ideally these payments would be made to entities that were taxed at a rate considerably lower than the U.S. tax rate. These payments eroded the base on which the U.S. tax would be calculated.

This section explains how the foreign source income is taxed in the U.S. It leads to many tax strategies.

\section{B. International Tax Planning}

As a result of the above rules many corporations developed international tax plans designed to reduce the amount of U.S. tax on their economic activities. These included inversion transactions whereby a U.S. corporation would convert to a foreign corporation while maintaining the same economic activities. Among other companies Burger King did this in its combination with Tim Hortons of Canada [3] and Medtronic merged with Covidien in Ireland [4]. The U.S. activities of these corporations remained subject to U.S. tax; whereas, the non-U.S. activities were no longer subject to U.S. corporate tax. Other planning involved paying royalties from a U.S. sub to its foreign parent such as was done by German corporation SAP [5].

Multinational corporations would also engage in transactions or set up structures to reduce non-U.S. tax. In the past some countries would not subject their domesticincorporated entities to taxation if the corporation was managed and controlled outside that country. A deductible payment from a corporation in a high tax jurisdiction to a related corporation that was managed and controlled in a low or zero tax entity such as the Cayman Islands could result in the income not being taxed anywhere.

International tax planning became so extensive that it caught the attention of the Organization of Economic Cooperation and Development (OECD) and the United States (U.S.) government.

In 2013, the OECD issued "Action Plan on Base Erosion and Profit Shifting (BEPS)," in which it developed fifteen action plans [6]. The plan pointed out that the profit shifting problems stemmed from international transactions that provided multinational corporations with opportunities to shift profits from one country to another.

In 2015, the OECD further developed the "Base Erosion and Profit Shifting Project: Action 15: A Mandate for the Development of a Multilateral Instrument on Tax Treaty Measures to Tackle BEPS," in which it laid out an instrument to implement the Action Plan [7]. To date, more than 100 countries have signed this agreement [8]. This is the action on the European side. 


\section{The U.S. Action To Curb Abuses}

The U.S. attacked the use of inversion transactions by tightening the rules under section 7478 . Under the new rules a U.S. corporation entering into an inversion transaction covered by the section would continue to be treated as a U.S. corporation even though legally it had changed its status to that of a foreign corporation. Thus, it continued to be taxed on its worldwide income.

Then in late 2017 the U.S. passed the TCJA with most provisions effective beginning in 2018. The U.S. corporate tax rate was reduced to $21 \%$, removing some of the incentives to shift income overseas. The TCJA also completely revamped the U.S. treatment of international tax transactions. Many different areas were revised in whole or in part. This paper focuses on three provisions designed to prevent the erosion of the U.S. tax base, the deferral of interest expense under revised section 163(j), the hybrid transactions and hybrid entities provision, and the "Base Erosion and Anti-Abuse Tax" (BEAT).

\section{A. An Overall Limitation on the Deduction of Interest Expense}

Revised section 163(j) now places a limit on interest expense deductions whether paid to U.S. or foreign taxpayers regardless of whether the payment is made to a related party. The limitation is generally $30 \%$ of business interest income plus adjusted taxable income. Adjusted taxable income is taxable income computed solely by reference to income, deductions, gains and losses from a trade or business, with exceptions for certain deductions, including after 2022 deductions for depreciation, amortization or depletion. The limitation does not apply to a corporation with average annual gross receipts of under $\$ 25$ million for the prior three years, or to certain businesses that can elect out of the provision [9].

The combination of revised section 163(j) and the BEAT rule discussed below, plus the decrease in the U.S. corporate tax rate to $21 \%$ may encourage highly leveraged corporations to shift some of their borrowing to foreign subsidiaries. Even though Section 163(j) provides an unlimited carryover of any disallowed interest, a deduction deferred will cause a loss of the time value of money for the deduction. Also if the payment is made to a foreign related party it is possible the related party may be subjected to a higher rate of tax on the interest income than the eventual benefit of the deduction in the U.S.

\section{B. A Specific Disallowance of Interest and Royalty Expense When Paid to a Related Party}

The second provision attacks base erosion payments that not only reduce U.S. tax but are structured so that the payment is not taxable (or taxed at a lower than normal rate) in the country of the recipient corporation. This highly technical provision permanently denies a deduction for interest and royalty payments made to a related party if the payment is pursuant to a hybrid transaction or is from or to a related hybrid entity [10].

A hybrid transaction would include an otherwise deductible interest or royalty payment for U.S. tax purposes that is not treated as such by the foreign tax law where the recipient is tax resident or is subject to tax. A hybrid entity is one where there is a mismatch between the U.S. and foreign tax law so the entity is treated as fiscally transparent by one of the jurisdictions but not by the other.

An exception is made for payments made by a U.S. corporation to a related foreign corporation where the payments are treated as subpart-F income since the result is no net tax deduction in the U.S. The Treasury Secretary is given broad discretion to issue necessary guidance to cover under this provision domestic or foreign branches and domestic entities even if they don't meet the statutory definition of a hybrid entity.

\section{The BEAT Provision Attacks on Base Erosion}

The third provision is the above-referenced BEAT provision under new section 59A. It applies to corporations with at least $\$ 500$ million of average gross receipts for the prior three years [11].

The $\$ 500$ million applies to U.S. corporations and foreign corporations to the extent of their income effectively connected with a U.S. trade or business. To prevent splitting up activities to avoid the $\$ 500$ million ceiling amount all corporations that are part of a controlled group (using the section 1563 rules but including foreign corporations) are treated as one taxpayer.

There is also a de minimis exception discussed below for taxpayers whose payments to related foreign parties are very small by comparison to total deductions. The thrust of the BEAT legislation is to permanently disallow otherwise taxdeductible payments made to related parties that effectively erode the U.S. tax base.

BEAT is in effect a new additional tax that operates similar to the old AMT in section 55 that was repealed by TCJA. Unlike the old AMT however there is no carryover of the BEAT tax so the result could be a permanent tax disallowance that under the GAAP rules could lead to a higher effective tax rate for some U.S. taxpayers.

The BEAT is the base erosion minimum tax amount for the year. The calculation involves taking 10 percent $(5 \%$ in 2018 and $12.5 \%$ beginning in 2025) of the modified taxable income and subtracting the taxpayer's regular tax liability after reduction for certain credits including the foreign tax credit. The rates are one percent higher for certain banks and securities dealers. Modified taxable income is taxable income with no deduction for any base erosion payment or a deduction for the portion of any net operating loss resulting from a base erosion payment in a prior year.

A base erosion payment is any deductible payment or accrual to a related foreign party. This includes depreciation, amortization and depletion if the particular asset was purchased from the related party. In general, cost of goods sold is not a base erosion payment except for payments to certain expatriated entities such as corporations doing an inversion. Payments for services eligible for the section 482 services cost method may also be excluded. If a payment otherwise subject to BEAT has full U.S. withholding tax that payment will not be subject to BEAT. If the withholding is reduced, for example by a tax treaty, a prorata portion of the payment will be subject to the BEAT calculation.

Note that BEAT applies to deductible payments, so for example any payment that would not be deductible because 
it was unreasonable in amount will not be affected by BEAT and presumably Section 482 will cover that payment to disallow the deduction. Any payment disallowed under the hybrid party legislation would presumably be treated the same, but any interest deferred because of section 163(j) will presumably be subject to BEAT at such time as the carryover of the interest deferred under section 163(j) is used.

A related party is any person that owns at least 25 percent of the vote or value of the taxpayer, and any person related to the taxpayer or to the 25 percent or more owner of the taxpayer within the meaning of the usual Section 267(b) and $707(b)(1)$ rules, and any person related to the taxpayer under section 482.

The de minimis exception referred to above excludes from the BEAT tax any taxpayer whose base eroding payments made to foreign related persons for a taxable year are less than three percent (two percent for certain banks and security dealers) of all deductions other than the NOL, the new participation exemption dividends received deduction and certain other deductions relating to foreign income that were introduced by TCJA.

\section{EXAMPLE - BASE ERosion AND ANTI-ABUSETAX}

American is a U.S. food company. Foreign is a non-U.S. company. American wholly owns Foreign. The following intercompany transactions occurred (numbers in millions).

(A). American has $\$ 800$ sales revenue.

(B). American paid $\$ 500$ to Foreign for the merchandise purchased.

(C). American paid $\$ 200$ to Foreign for interest on an intercompany loan.

(D). American reports net income of $\$ 100$.

The regular taxable income, regular tax liability, base erosion payment, modified taxable income, modified tax liability, base erosion and anti-abuse tax (BEAT), and final tax liability, are computed as follows (numbers in millions):

(1). Regular taxable income $=\$ 100(800-500-200)$.

(2). Regular tax liability $=\$ 21(100 \times 21 \%)$.

(3). Base erosion payment $=\$ 200$ (the interest expense).

(4). Modified taxable income $=\$ 300(100+200)$.

(5). Modified tax liability $=\$ 30(300 \times 10 \%)$.

(6). Base erosion and anti-abuse tax $($ BEAT) $=\$ 9(30-$ 21).

(7). Final tax liability $=\$ 30(21+9)$.

Here are some important observations. The $\$ 500$ cost of merchandise is not a base erosion payment because it is cost of goods sold. It is not a vehicle for income shifting. However, the $\$ 200$ intercompany interest expense does shift income from American to Foreign. It is added back in determining modified taxable income, $\$ 300(100+200)$. The base erosion and anti-abuse tax rate is 10 percent. Modified tax liability is $\$ 30(300 \times 10 \%)$. This leads to $\$ 9(30-21)$ of base erosion and anti-abuse tax (BEAT). The final tax liability is $\$ 30(\$ 21+9)$.

\section{Strategies For "BASE Erosion And Anti-Abuse TAX}

The BEAT is a completely new tax created to reduce abusive erosion of the U.S. tax base. However, some strategies may be used to alleviate this additional tax burden.

(A). The BEAT applies only to companies having at least $\$ 500$ million in gross receipts a year. If gross receipts reach $\$ 500$ million, it will be difficult to avoid BEAT since section 1563 controlled group rules are used to determine who is subject to the tax. In the case of foreign corporations however only their income effectively connected with a U.S. trade or business is taken into account.

(B). Only the payment from a U.S. corporation or U.S. branch with income effectively connected with a U.S. trade or business results in a base erosion payment added back to modified taxable income. If a U.S. parent hires its related CFC to perform service, and the CFC in turn hires an unrelated third party to perform this work, the payment from the U.S. parent to the CFC still would be treated as a base erosion payment and added back to modified taxable income. A better strategy may be to let the U.S. parent directly hire this unrelated third party to perform the work and avoid treating the payment as a base erosion payment.

(C). Similarly, for example, if both the U.S. parent and CFC are software development companies, parent may pay the CFC $\$ 100,000$ for a research project. The CFC, in turn, pays $\$ 20,000$ to an unrelated subcontractor to perform part of the project. The entire $\$ 100,000$ payment from the U.S. parent to the CFC would be treated as a base erosion payment and added back to modified taxable income. If the U.S. parent directly pays the $\$ 20,000$ project fee to the unrelated third party, only the $\$ 80,000$ paid directly to the related CFC would be treated as a base erosion payment.

(D). In another similar situation, for example, the U.S. parent pays $\$ 100,000$ to a CFC to perform research work on a medical patent. An unrelated third party uses this medical patent and pays $\$ 30,000$ fee to U.S. parent. The entire $\$ 100,000$ payment from U.S. parent to the CFC would be treated as a base erosion payment and added back to modified taxable income. In truth, this $\$ 30,000$ fee is intended to be compensation for the CFC's research work. A better strategy might be to let the $\mathrm{CFC}$ receive the $\$ 30,000$ fees from the unrelated third party. As a result, the "base erosion payment" to be added back would be reduced from $\$ 100,000$ to $\$ 70,000(100,000-30,000)$.

(E). Only the base erosion payment is counted in determining the BEAT. The definition of the base erosion payment is not always clear. For example, both the U.S. parent and the CFC are consulting firms. The U.S. parent consulted the $\mathrm{CFC}$ on some technical issues paying consulting fees. Are the fees counted as base erosion payment to be added back to modified taxable income? It depends on the cost of the consulting services. If the CFC is generating a profit on the charge the fee will be a base erosion payment. This may lead to the issue of what costs in addition to the salaries etc. of the service providers need to be included in the "cost" of the service."

(F). The regular cost of goods sold between the U.S. parent and a CFC is not counted as a base erosion payment and thus is not added back to modified taxable income. For 
example, both the U.S. parent and the CFC are pharmaceutical companies. The U.S. parent purchases chemicals from the CFC to manufacture medicine. As long as the payment is within the section 482 guidelines no base erosion payment is made.

(G). If the U.S. parent purchases merchandise directly from a CFC other than what goes into cost of goods sold, it may constitute a base erosion payment. A better strategy, albeit it counter-intuitive may be to purchase it from an unrelated third-party competitor. This would avoid having to add back depreciation or other cost recovery charges. It requires to run the numbers to see which result is better.

(H). If the U.S. parent borrows money from a CFC, the interest payment could constitute a base erosion payment. Corporations will have to run the numbers. It may ironically be better to borrow money from a bank than to try to borrow from a foreign subsidiary. Alternatively, given the new Participation Exemption under new section 245A (which excludes from gross income certain dividends from $10 \%$ or more owned foreign corporations) it may be better to repatriate the CFC's funds to the U.S.

(I). BEAT is the excess of the modified tax liability over the regular tax liability. If it appears that a company may be subject to BEAT in a particular year, as part of normal yearend tax planning strategy it may be possible to accelerate non-related party taxable income into the current year or defer expenses to a later year to reduce or perhaps eliminate the BEAT exposure.

No doubt other strategies will be developed to minimize the additional burden of the BEAT. The guiding principle is to avoid the treatment as an intercompany transaction. It may be more advisable to deal with an unrelated third party than the U.S. parent company's own CFC.

\section{CONCLUSION}

The TCJA introduces several new and very complex tax rules dealing with international tax. Many of the rules are interconnected so that running afoul of one provision may trigger an adverse result in other areas. It will be incumbent on U.S. tax planners to do extensive research and run alternative scenarios to discover the impact of this new legislation on a particular transaction or strategy. This article serves as an introduction to some of the more important concepts.

\section{REFERENCES}

[1] “Tax Cuts and Jobs Act of 2017," P.L. 115-97, enacted December 22, 2017.

[2] C. Dulaney, "Repatriation Frenzy is just Starting," The Wall Street Journal, June 28, 2018, Vol. CCLXXI No. 150, p. B10.

[3] L. Hoffman, and D. Mattioli, "Burger King in Talks on Canada Deal," The Wall Street Journal, August 25, 2014, p.A1.

[4] L. Hoffman, "The Tax Inversion Wave Keeps Rolling," The Wall Street Journal, July 8, 2014 p. C1.

[5] S. Schechner and N. Trentmann, "Foreign Companies Fret About U.S. Tax, The Wall Street Street Journal, February 14, 2018, p. B5.

[6] Organization of Economic Cooperation and Development (OECD, 2013), "Action Plan on Base Erosion and Profit Shifting," 2013, available online at https://www.oecd.org/ctp/BEPSActionPlan.pdf, retrieved June 1, 2018.

[7] OECD (2015). "Base Erosion and Profit Shifting Project: Action 15: A Mandate for the Development of a Multilateral Instrument on Tax Treaty Measures to Tackle BEPS," available online at https://www.oecd.org/tax/beps/beps-action-15-mandate-fordevelopment-of-multilateral-instrument.pdf, retrieved June 1, 2018.

[8] OECD (2016), "Multinational Convention to Implement Tax Treaties Related Measures to Prevent Base Erosion and Profit Shifting," Paris, France, December 24, 2016, available online at http://www.oecd.org/tax/treaties/multilateral-convention-toimplement-tax-treaty-related-measures-to-prevent-BEPS.pdf, retrieved June 1, 2018.

[9] Internal Revenue Code (IRC) §163(j)(3).

[10] Ibid $267 \mathrm{~A}$.

[11] Ibid §59A(e)(1)(B). 